\title{
Structure and ecological indices of fish assemblages in the recently restored Al-Hammar Marsh, southern Iraq
}

\author{
Najah A. Hussain', Abdul-Razak M. Mohamed², Sajed S. Al Noo², \\ Falah M. Mutlak ${ }^{3}$, Ibrahim M. Abed², Brian W. Coad ${ }^{4}$
}

I Department of Biology, College of Science, University of Basrah, Iraq 2 Department of Fisheries and Marine Resources, College of Agriculture, University of Basrah, Iraq 3 Marine Science Centre, University of Basrah, Iraq 4 Canadian Museum of Nature, Ottawa, Canada

Corresponding author: Najah A. Hussain (dr_najah_h@yahoo.com)

Academic editor: F. Krupp | Received 10 March 2009 | Accepted 16 December 2009 | Published 28 December 2009

Citation: Hussain NA, Mohamed A-R M, Al Noor SS, Mutlak FM, Abed IM, Coad BW (2009) Structure and ecological indices of fish assemblages in the recently restored Al-Hammar Marsh, southern Iraq. In: Krupp F, Musselman LJ, Kotb MMA, Weidig I (Eds) Environment, Biodiversity and Conservation in the Middle East. Proceedings of the First Middle Eastern Biodiversity Congress, Aqaba, Jordan, 20-23 October 2008. BioRisk 3: 173-186. doi: 10.3897/biorisk.3.11

\begin{abstract}
The aim of the present study is to determine the species composition, the structure of the fish assemblages, and to develop ecological indices in the restored east Al-Hammar Marsh. Fish were collected from October 2005 to September 2006 at two stations (Mansoury and Burkah). Fish samples contained freshwater species, both native and alien, and marine species. Thirty-one species were collected, eleven of them marine, the rest freshwater. Native species numbered 14 (45\%), alien species 6 (19\%) and marine species 11 (36\%). Resident species formed $32.2 \%$, seasonal species $16.0 \%$ and occasional species $51.6 \%$ of the fauna. The abundance of species varied, Liza abu being the most dominant species, with Carassius auratus ranking second and Acanthobrama marmid ranking third, comprising $35.8 \%, 23.6 \%$ and $10.6 \%$ respectively. Ecological indices were as follows: diversity ranged from 1.07 in November to 2.01 in July, richness ranged from 0.74 in December to 2.83 in July, and evenness ranged from 0.48 in November to 0.84 in December. The highest monthly similarity was in May at $77 \%$ and lowest in December at $29 \%$. Water temperature showed medium correlations (0.62 and 0.58 ) with both the number of species and the total catch, respectively, while salinity exhibited weak positive correlations ( 0.05 and 0.26 ) with both the number and the total catch of species, respectively. Temperature is related to species number, presumably as a surrogate for many other seasonal changes.
\end{abstract}

\section{Keywords}

Species composition, fish assemblage, ecological indices, tidal marsh diversity, Mesopotamian marshes, alien species, Iraq

Copyright Najah A. Hussain et al. This is an open access article distributed under the terms of the Creative Commons Attribution License, which permits unrestricted use, distribution, and reproduction in any medium, provided the original author and source are credited. 


\section{Introduction}

The marshes of southern Iraq were the largest wetlands in south-western Asia, covering more than $15,000 \mathrm{~km}^{2}$ and representing about $44 \%$ of the inland freshwater bodies of Iraq. These marshes were a natural refuge for many aquatic organisms, especially fish and waterfowl. The environmental, hydrological and physiographical setting formed a unique ecosystem, allowing high biodiversity and richness of the aquatic biota. The marshes were also characterized by their productivity (Al-Hilli 1977, Al-Hilli et al. 2009, Al-Zubaidy 1985, Al-Mayah 1992) and consequently were the richest and rarest biotope in the region. The Mesopotamian marshes were considered by FAO (1999) as the major source of inland fisheries (60\%) in Iraq, estimated at 23,600 tonnes (Partow 2001). They were the permanent habitat for millions of waterfowl and a flyway for millions more migrating between Siberia and Africa (Evans 2002).

Al-Hammar Marsh is situated south of the Euphrates River and extends from Nasiriyah City in the west of Iraq to the outskirts of Basrah City on the Shatt al-Arab River in the east. To the south is the saline-brackish Main Outfall Drainage (MOD) channel, sabkhas and the sand dune belt of the southern desert. The marsh area comprises $2800 \mathrm{~km}^{2}$ of permanent marsh, expanding to over $4500 \mathrm{~km}^{2}$ during the period of spring flooding and temporary inundation (Iraq Foundation 2003).

The formation of Al-Hammar Marsh was due to the deposition of the suspended load of the Tigris-Euphrates rivers and resulted in a shift from brackish lagoon and coastal marsh to inland marsh, occupied by fresh to brackish water (Aqrawi 1993, Aqrawi and Evans 1994).

Al-Hammar Marsh is the largest southern marsh extending through two provinces (Basrah and Nasiriyah). It is approximately $120 \mathrm{~km}$ long and $25 \mathrm{~km}$ wide. Maximum water depth in the marsh ranges from $1.8 \mathrm{~m}$ to $3.0 \mathrm{~m}$. The marsh narrows about its middle, and consequently can be divided roughly into two parts, west and east, connected by a shallow channel (Fig. 1).

Planned drainage processes started in the early 1990s to divert the riverine water of the Tigris, Euphrates and Shatt al-Arab rivers away from the southern marshlands, resulting in a catastrophic loss of the native aquatic flora and fauna. In 2002, 93\% of the permanent marshes defined in 1973 had been destroyed. Only 14.5\% of the AlHammar Marsh remained (Richardson and Hussain 2006). Since 2003, great efforts have been made to restore the marshes and revive the wetlands environment. As of August 2007, the marshes had recovered almost 58\% of their former area in 1972 according to UNEP/IMOS (2007).

After reflooding in April 2003, the west part of Al-Hammar Marsh was fed primarily from tributaries of the Euphrates, but the eastern part received a considerable amount of water from the Shatt al-Arab River, and groundwater recharge was another source of replenishment. The eastern part of Al-Hammar is a tidal marsh affected by the semi-diurnal tide from the Arabian Gulf, with well oxygenated oligohaline water, grey mud-silt sediments with low total organic carbon (TOC), and an alkaline $\mathrm{pH}$ (Hussain and Taher 2007, Tahir et al. 2008). 


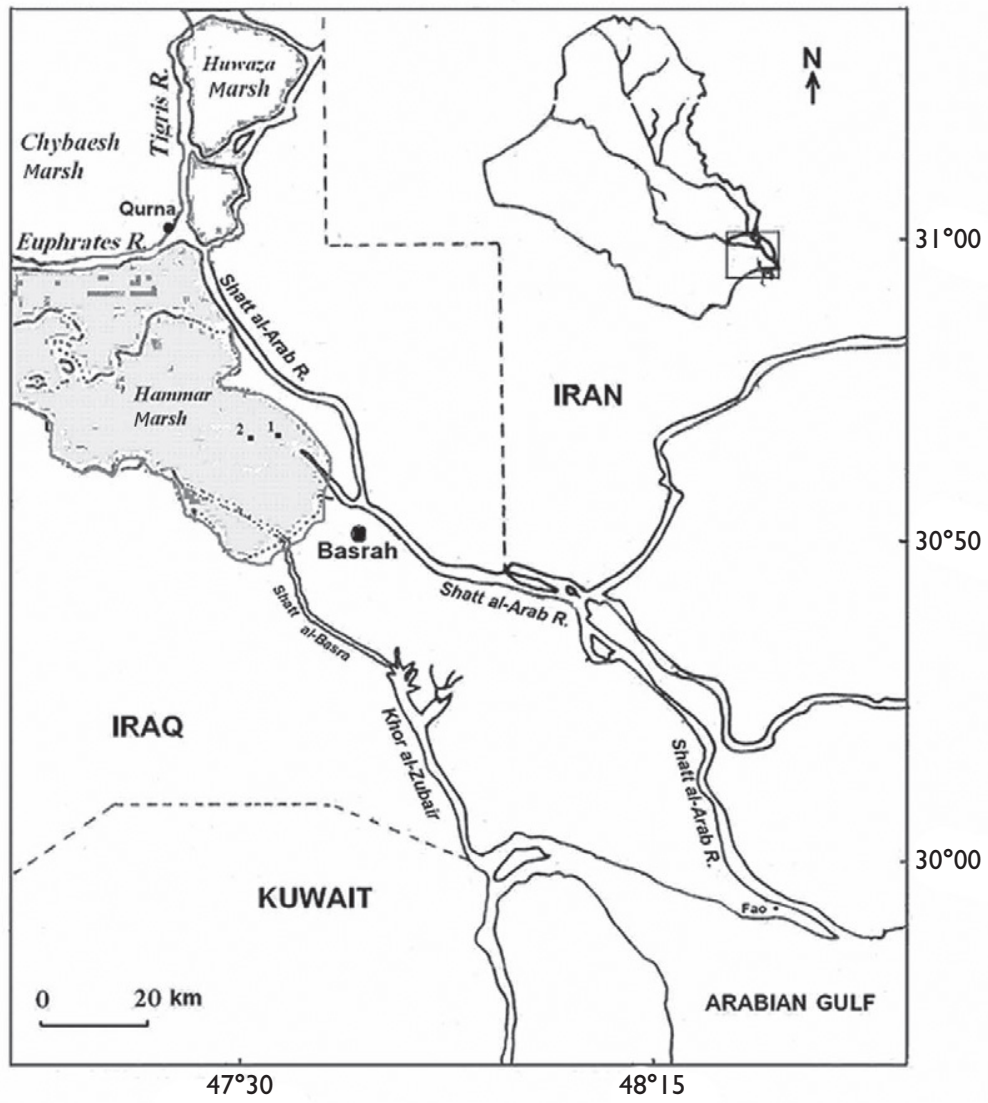

Figure I. Map of southern of Iraq, showing the location of Al-Hammar Marsh (I Mansoury Site, 2 Burkah Site).

The structure of the fish assemblage in the southern marshes has not been studied. A few taxonomic works refer to the marshes in passing (Khalaf 1961, Mahdi 1962, Coad 1991) and recently reports on the environmental restoration of the southern marshes have appeared (e.g., IMRP 2006, ARDI 2006) along with articles concerned with the occurrence and biology of marine and diadromous fish (Mohamed et al. 2009). Most previous studies have focused on biological aspects of some of the freshwater fishes in Al-Hammar Marsh (Barak and Mohamed 1983, Dawood 1986, Jasim 1988, Al-Sayab 1989, Al-Kanaani 1989).

The aim of the present study is to determine the structure of the fish assemblage and the species composition in the restored Al-Hammar Marsh. Previously, no studies were conducted on the diversity of the fishes, taking into consideration their relative abundance, the monthly changes in ecological indices, and the similarity between sampled months coupled with the effects of environmental factors like water temperature and salinity. 


\section{Material and methods}

From October 2005 to September 2006, fishes were collected monthly from two

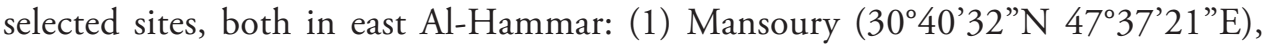
environmentally considered as a tidal channel marsh and desiccated freshwater sta-

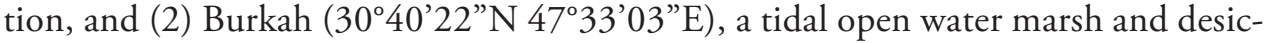
cated station (Fig. 1). Sampling was carried out using a seine net $(20 \mathrm{~m}$ long with a $2.5 \mathrm{~cm}$ mesh), fixed gill nets ( $50 \mathrm{~m}$ to $100 \mathrm{~m}$ long with $2.5 \mathrm{~cm}$ to $10 \mathrm{~cm}$ mesh size), and electro-fishing gear. Specimens were immediately transported to the laboratory on crushed ice. Water temperature and salinity were measured to determine the relationships of these two factors with the number of species and total catch of species. Fishes were identified to species by using Khalaf (1961), Mahdi (1962), Beckman (1962) and Coad (1991).

The ecological indices of the fish assemblage in east Al-Hammar Marsh, namely relative abundance, diversity, evenness, richness and similarity were calculated monthly according to Odum (1970), Shanon and Weaver (1949), Pielou (1977), Margalef (1968) and Boesch (1977), respectively. Fish species were divided into three categories according to their temporal occurrence in the monthly samples following Tyler (1971).

\section{Results}

\section{Effects of abiotic factors}

The monthly fluctuations in air and water temperatures and salinity in east Al-Hammar Marsh are illustrated in Fig. 2. Air temperature ranged from $15^{\circ} \mathrm{C}$ in February to $33^{\circ} \mathrm{C}$ in June and water temperature changed from $12.5^{\circ} \mathrm{C}$ in February to $29^{\circ} \mathrm{C}$ in July. The minimum value of salinity was $1.2 \mathrm{mg} / \mathrm{l}$ in August and the maximum value was $2.0 \mathrm{mg} / \mathrm{l}$ in May and July.

The relationships of water temperature and salinity with the total catch of individuals and the number of species in Al-Hammar Marsh are shown in Fig. 3. Water temperature showed a significant positive correlations with the number of species $(\mathrm{r}=$ $0.620, \mathrm{p}<0.05)$ and the total catch of fish individuals $(\mathrm{r}=0.578, \mathrm{p}<0.05)$, while the salinity showed very weak positive correlations with both of them, $\mathrm{r}=0.056$ and $\mathrm{r}=$ $0.262, \mathrm{p}<0.05$, respectively.

\section{Species composition and temporal occurrence}

The overall number of fish species caught from the marsh was 31, belonging to 14 families (Table 1). Cyprinidae, the dominant family in terms of number of species was represented by 12 species: Aspius vorax, Carassius auratus, Barbus luteus, B. sharpeyi, B. xanthopterus, B. grypus, Cyprinus carpio, Ctenopharyngodon idella, Acanthobrama 


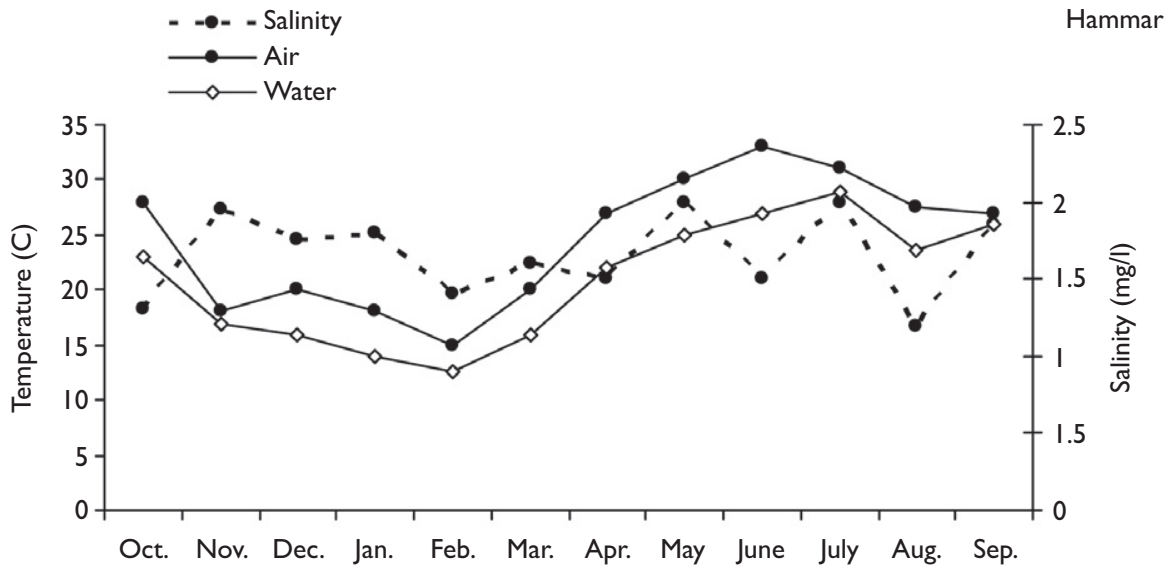

Figure 2. Monthly fluctuations in air, water temperature and salinity in east Al-Hammar Marsh (2005-2006).

marmid, Cyprinion macrostomum, Alburnus mossulensis, and Alburnus sp. Other species belonged to the families Mugilidae (Liza abu, L. subviridis and L. klunzingeri), Sparidae (Acanthopagrus latus and A. berda), Cyprinodontidae (Aphanius dispar and A. mento), Poeciliidae (Gambusia holbrooki and Poecilia latipinna), Gobiidae (Bathygobius fuscus and Boleophthalmus dussumieri), Clupeidae (Tenualosa ilisha), Siluridae (Silurus triostegus), Mastacembelidae (Mastacembelus mastacembelus), Heteropneustidae (Heteropneustus fossilis), Engraulidae (Thryssa whiteheadi), Scatophagidae (Scatophagus argus), Hemiramphidae (Rhynchorhamphus georgii), and Soleidae (Brachirus orientalis).

The fish fauna of eastern Al-Hammar Marsh may be broadly classified into three groups: native freshwater, alien and marine fish species. Fourteen native freshwater species (Aspius vorax, Barbus luteus, B. sharpeyi, B. xanthopterus, B. grypus, Acanthobrama marmid, Alburnus mossulensis, Alburnus sp., Cyprinion macrostomum, Liza abu, Aphanius dispar, A. mento, Silurus triostegus and Mastacembelus mastacembelus) constituted 45.1\% of the total number of species. Six alien freshwater species (Cyprinus carpio, Heteropneustus fossilis, Gambusia holbrooki, Carassius auratus, Ctenopharyngodon idella and Poecilia latipinna) formed $19.4 \%$ of the total number of species. Eleven marine species (Tenualosa ilisha, Liza subviridis, L. klunzingeri, Acanthopagrus latus, A. berda, Boleophthalmus dussumieri, Thryssa whiteheadi, Scatophagus argus, Bathygobius fuscus, Rhynchorhamphus georgii and Brachirus orientalis) comprised $35.5 \%$ of the total number of species.

The monthly variations of native, alien and marine species in Al-Hammar Marsh are illustrated in Fig. 4. The highest numbers of total, native and marine species were in July and the lowest in December. There was a slight variation in the number of alien species throughout the year.

Species occurring temporally in the Al-Hammar Marsh were classified into three groups. The resident species were ten. Four of them appeared in all 12 months (Liza abu, L. subviridis, Carassius auratus and Acanthobrama marmid), one in 11 months 
(Barbus luteus), four in 10 months (Cyprinus carpio, Aspius vorax, Alburnus mossulensis and Heteropneustus fossilis) and one in nine months (Silurus triostegus). The resident species, forming $32.3 \%$ of the total number, consisted of native, alien and marine species. Of the five seasonal species, Thryssa whiteheadi was captured in eight months and Tenualosa ilisha and Barbus sharpeyi in seven months, and the remaining two in six months (Bathygobius fuscus and Aphanius dispar). The seasonal species comprised $16.1 \%$ of the total number of species and the occasional species $51.6 \%$. Sixteen species were categorized as occasional, two of them appeared in three months (Aphanius mento and Cyprinion macrostomum), two in two months (Barbus xanthopterus and Acantho-

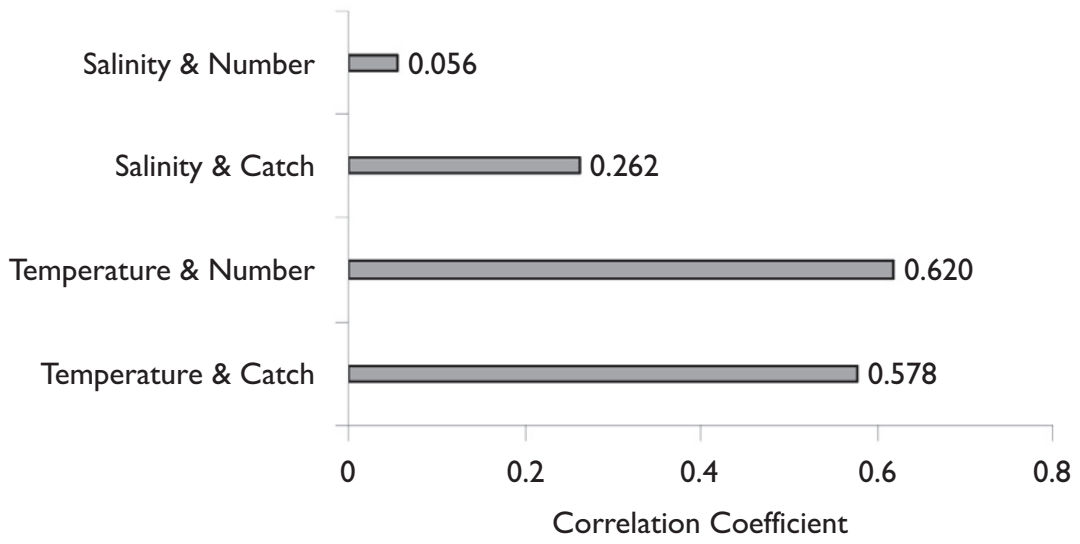

Figure 3. The relationships of water temperature and salinity with the total catch of individuals and the number of species in Al- Hammar Marsh

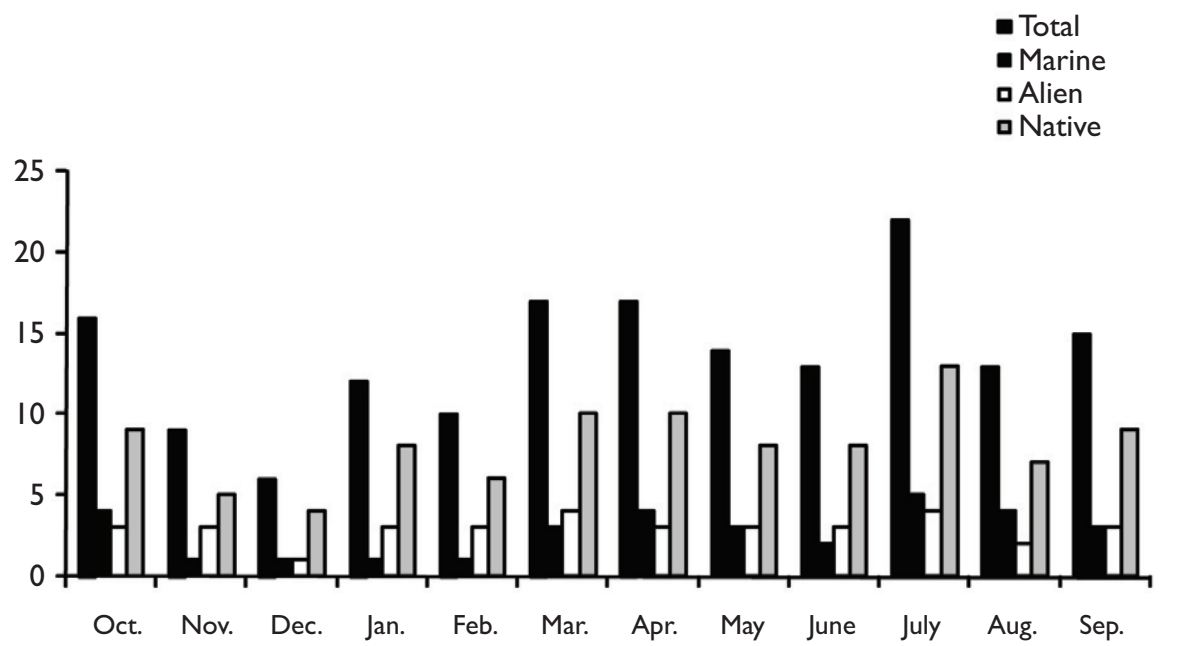

Figure 4. Monthly occurrence of total, native, alien and marine species in Al-Hammar Marsh 
pagrus latus) and twelve in one month (Barbus grypus, Mastacembelus mastacembelus, Boleophthalmus dussumieri, Scatophagus argus, Gambusia holbrooki, Ctenopharyngodon idella, Acanthopagrus berda, Rhynchorhamphus georgii, Poecilia latipinna, Brachirus orientalis, Liza klunzingeri and Alburnus sp.).

The monthly variation of similarity of fish species composition in the marsh during the study period is shown in Fig. 5. The highest similarity level was found during May (77\%) and the lowest during December (29\%). Generally, the similarity level was high during the spring and summer months.

\section{Relative abundance and ecological indices}

A total of 16,199 fishes belonging to 31 species were collected from Al-Hammar Marsh, the highest number (2920) being in September and the lowest (800) in December. Liza abu was the most abundant species comprising $35.9 \%$ of the total number followed by Carassius auratus (23.6\%), Acanthobrama marmid (10.8\%) and Tenualosa ilisha (10.1\%). The previous four species accounted for over $80 \%$ of the total catches. Liza abu was the dominant species throughout the year except October, with a peak in April. Carassius auratus was second in dominance (Table 1).

Monthly variations in ecological indices of species are illustrated in Fig. 6. The diversity index fluctuated from 1.07 in November to 2.01 in July, with an overall value of 1.53 . The richness index ranged from 0.74 in December to 2.83 in July, with an overall value of 1.76 . The evenness index ranged from 0.48 in November to 0.84 in December, with an overall value of 0.60 .

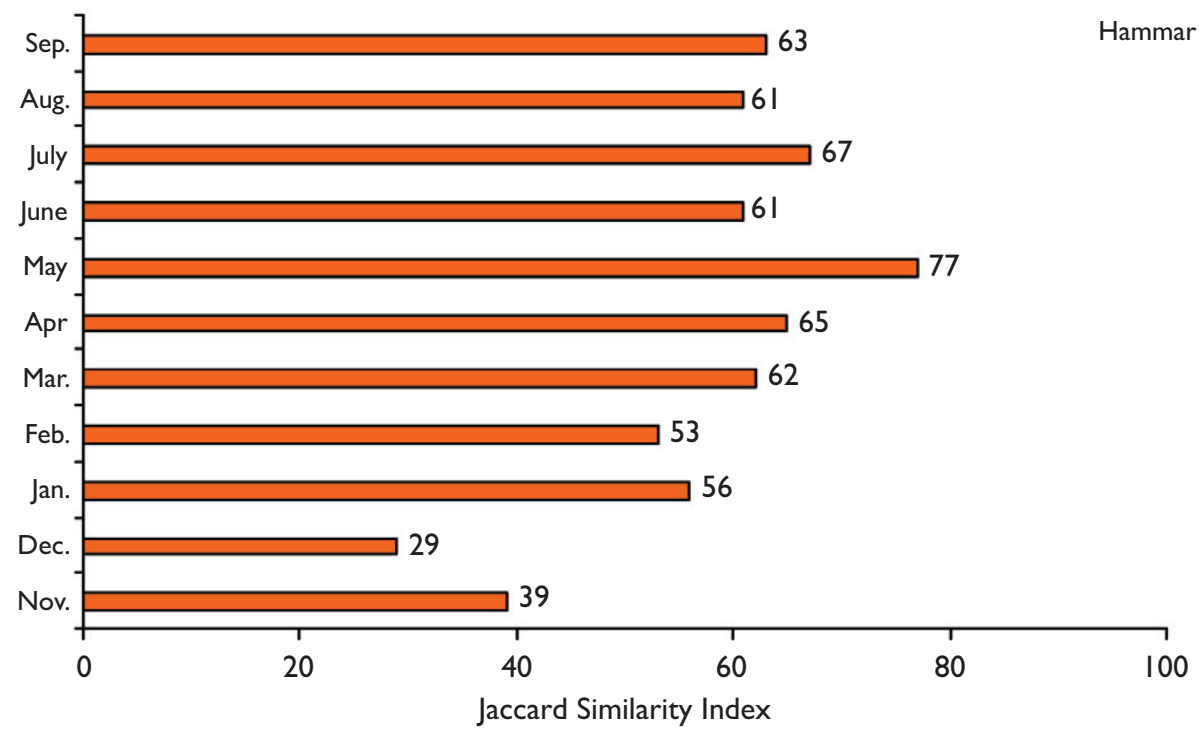

Figure 5. Monthly variations of similarity of species in Al-Hammar Marsh 


\begin{tabular}{|c|c|c|c|c|c|c|c|c|c|c|c|c|c|c|c|c|c|c|c|c|c|c|}
\hline 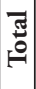 & & : & 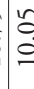 & 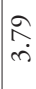 & $\dot{m}$ & \begin{tabular}{l|l} 
& \\
$\infty$ & 1 \\
$i$ & $i$
\end{tabular} & & & 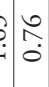 & $\left|\begin{array}{l}\infty \\
0 \\
0 \\
0\end{array}\right|$ & & $\because$ & \begin{tabular}{l|l}
0 & $\bar{n}$ \\
$\vdots$ & 0 \\
0 & 0
\end{tabular} & 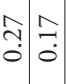 & $\stackrel{n}{0}$ & $\begin{array}{lll} & \tilde{n} \\
\dot{0} & 0 \\
0\end{array}$ & 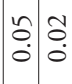 & $\begin{array}{l}1 \\
0 \\
0 \\
0\end{array}$ & $\begin{array}{lll}0 & 0 \\
\vdots & \vdots \\
\vdots & \vdots \\
0 & 0\end{array}$ & & $\begin{array}{l}0 \\
\vdots \\
0 \\
0\end{array}$ & \\
\hline ڤे & & $\begin{array}{l}0 \\
\vdots \\
1\end{array}$ & $\mid \begin{array}{ll}0 \\
\infty \\
\infty \\
c\end{array}$ & $\stackrel{g}{ \pm}$ & $\begin{array}{c}\curvearrowright \\
\dot{m}\end{array} \mid$ & $\hat{\circ}$ & \begin{tabular}{l|l}
$\infty$ & \\
$i$ & $i$
\end{tabular} & તָ & 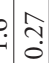 & $\begin{array}{c}0 \\
0 \\
0\end{array}$ & $\stackrel{\text { ô }}{\circ}$ & & & $\stackrel{n}{\sim}$ & ?ֶ: & & & & & & & \\
\hline 紫 & & $\begin{array}{l}\text { is } \\
\text { is }\end{array}$ & $\stackrel{+}{-}$ & $\hat{\infty}$ & & 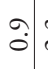 & $\stackrel{m}{i}$ : & 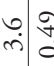 & $\stackrel{0}{\circ}$ & & ชี & & & & $\overrightarrow{0}$ & & & & & $\overline{0}$ & & \\
\hline 롤 & ป. & $\begin{array}{c}c \\
\dot{s}\end{array}$ & 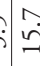 & 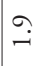 & $\left|\begin{array}{l}\infty \\
0 \\
0\end{array}\right|$ & $\stackrel{\sim}{\sim}$. & 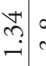 & \begin{tabular}{l|l}
$\infty$ & $\stackrel{0}{\oplus}$ \\
$\dot{m}$ &
\end{tabular} & 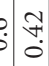 & $\stackrel{1}{\stackrel{0}{0}}$ & $\checkmark) \stackrel{m}{\sim}$ & : & & $\stackrel{0}{\circ}$ & $\hat{0}$ & 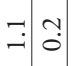 & & $\stackrel{\infty}{\longrightarrow}$ & & & & 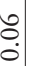 \\
\hline 䇂 & & & & $\stackrel{*}{0}$ & $\exists$ & $\exists$ & $\overrightarrow{6}: 7$ & $\exists \partial$ & ?ै. & $\hat{0}$ & & & $\stackrel{t}{0}$ & $\overrightarrow{0}$ & & & & & & & & \\
\hline$\sum^{\pi}$ & & o & c & $\hat{o}$ & 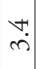 & $\stackrel{\stackrel{2}{\triangle}}{=}$ & $\stackrel{\dot{m}}{c}$ & $\tilde{i}$ & 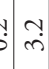 & $\tilde{o}$ & & $\stackrel{2}{0}$ & & $\stackrel{\nabla}{0}$ & & & & & & & & \\
\hline 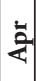 & & 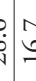 & 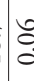 & $\stackrel{7}{?}$ & $\stackrel{\approx}{\approx}$ & خิ & $\hat{o}$ & 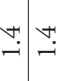 & $\approx \tilde{\tau}$ & $\mid$\begin{tabular}{c}
$\infty$ \\
\multirow{\lambda}{*}{} \\
$\dot{\lambda}$
\end{tabular} & & & $\begin{array}{l}\stackrel{+}{1} \\
\stackrel{0}{0}\end{array}$ & $\stackrel{+}{2}$ & $\mid \begin{array}{l}0 \\
0 \\
0\end{array}$ & $\begin{array}{l}\circ \\
\stackrel{0}{0} \\
\dot{0}\end{array}$ & & & & & : & \\
\hline
\end{tabular}

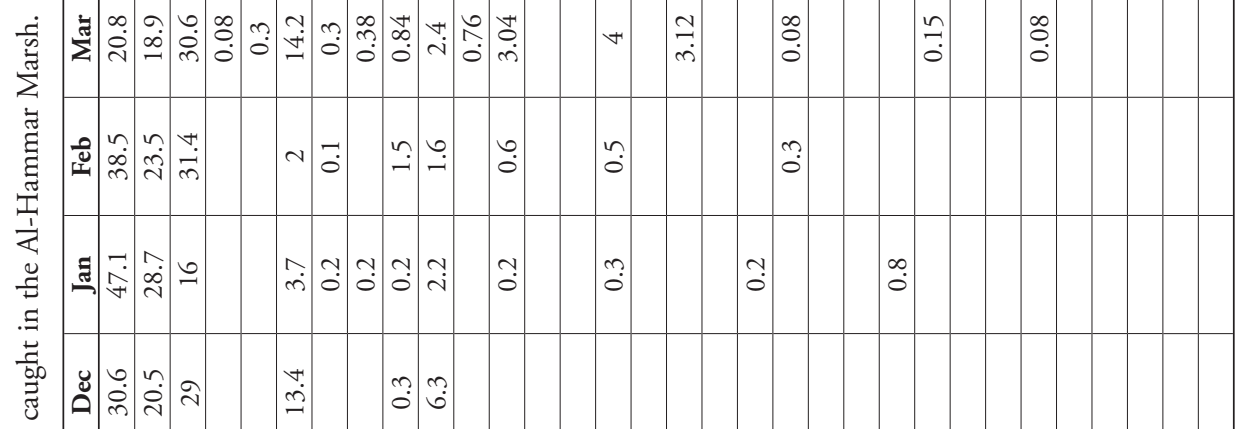

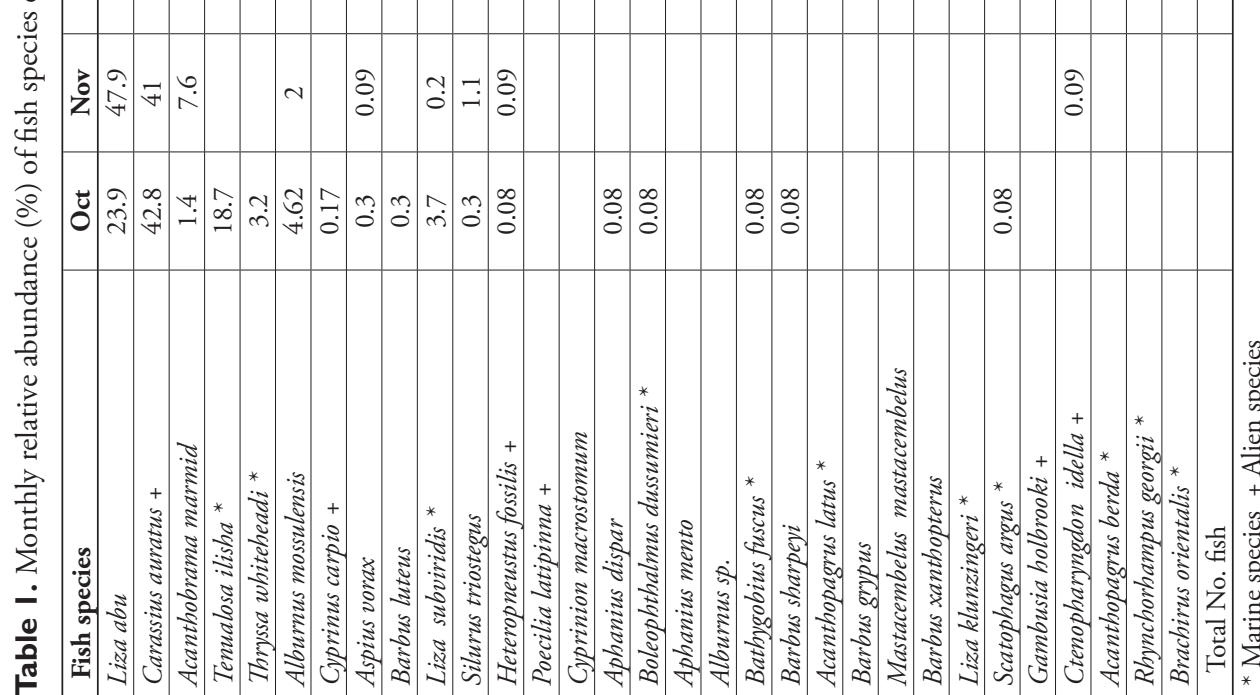




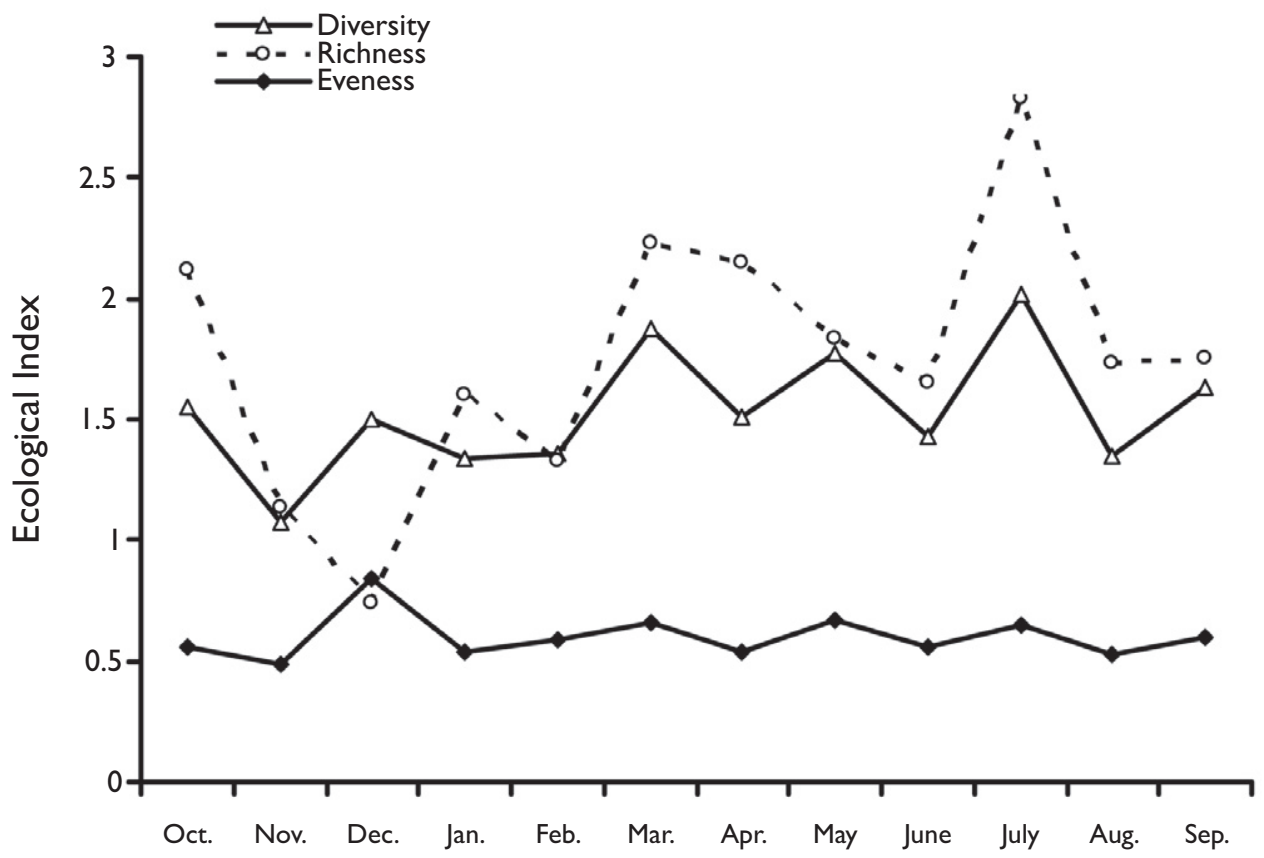

Figure 6. Monthly variations in ecological indices of fish species composition in Al-Hammar Marsh.

\section{Discussion}

Coad (1991) gave the total number of fishes in fresh waters of Iraq as 58 consisting of 43 freshwater, eight marine and seven exotic species. The number of species collected from the restored Al-Hammar Marsh was 31, nearly similar to a previous estimate by Al-Daham (1982) at 33 for all southern marshes. However, the species constitution was different from historical observations, several freshwater species having disappeared due to the long desiccation and degradation of the Al-Hammar environment, and the numbers being added to by more alien and marine species (Khalaf 1961, Mahdi 1962).

The deterioration of water quality of the Al-Hammar Marsh led to several cyprinid species disappearing even before the desiccation, e.g., Barbus subquincunciatus and $B$. scheich, which disappeared due to an increase in salinity from $0.4 \mathrm{~g} / \mathrm{l}$ in the 1970s (Al-Saadi et al. 1981) to 6.3g/l in the early 1990s (Al-Rikabi 1992). After inundation in 2003, a few native species substantially decreased in number, e.g., Barbus xanthopterus and B. grypus with very low relative abundance $0.02 \%$ and $0.05 \%$ respectively, due to scarcity of benthic food resources (insects and mollusks), competition with the alien species Cyprinus carpio (Al-Kanaani 1989), and increased salinity. Other native species became rare due to the loss of their habitat to the introduced species, e.g., Barbus sharpeyi to Ctenopharyngodon idella and Barbus luteus 
to Carassius auratus as indicated by their low abundance (Richardson 2008, Barak and Mohamed 1983, Jasim 1988). In general, the freshwater species composition of Al-Hammar Marsh was similar to other southern Iraqi marshes indicating that desiccation altered the fish composition in all southern marshes (Hussain et al. 2008, Richardson 2008).

The most abundant species in Al-Hammar, Liza abu, Carassius auratus and Acanthobrama marmid, were identical to other southern marshes because the ichthyofauna was originally derived from the Tigris, Euphrates and Shatt al-Arab rivers. The major difference was the seasonal occurrence of marine species in the Al-Hammar Marsh, but not in other southern marshes (CIMI 2006). The abundance of marine species led to an increase in richness, evenness and diversity indices and created seasonal fluctuation in relative abundance and total number of individuals in comparison with other freshwater marshes of southern Iraq (Hussain et al. 2006, Richardson 2008).

Because of the lack of data on the marshes before desiccation, comparisons were made with studies on other Iraqi lakes and reservoirs. During the 1980s, Epler et al. (2001) found in Habbaniyah, Tharthar and Razzazah lakes (central Iraq) that Liza abu was the most abundant species followed by Alburnus mossulensis. In the late 1990s, Al-Rudainy et al. (1999, 2001) showed that the fish assemblages in Habbaniyah Lake and Al-Qadisiya Reservoir (western Iraq) were also dominated by Liza abu and Carassius auratus, similar to the situation in Al-Hammar Marsh and other southern marshes (Hussain et al. 2006, 2008; Mohamed et al. 2009).

Higher diversity and richness in the eastern Al-Hammar Marsh during summer (July) could be due to recruitment of resident species after spring spawning (Ahmed et al. 1984, Dawood 1986, Jasim 1988, Naama et al. 1986), more individuals brought with the spring flood from the Euphrates River, and to the penetration of marine species especially anadromous ones such as Tenualosa ilisha and Liza subviridis. Emigration of marine species back to the Shatt al-Arab Estuary and the Arabian Gulf in winter (December) (Mohamed et al. 2009), led to higher evenness values and return of the fish assemblage to its stable state consisting of resident freshwater species during winter and early spring. Monthly similarity was the highest in May (77\%), coinciding with the gathering of many freshwater species for spawning. The September peak in total number of individuals was due to an increase in number of $T$. ilisha juveniles (Mohamed et al. 2009).

Temperature has a stronger correlation with number of species and the total number of individuals (catch) than salinity. Increase of temperature in spring and summer accelerated the productivity cycle of plankton and also decomposition rates of organic materials, i.e. more food resources become available for fish (Hammadi et al. 2007, Al-Sodani et al. 2007). The same conclusion was reached for the Khor Al-Zubair lagoon by Ali and Hussain (1990), reflecting that temperature was more related to species abundance than salinity in this tidal marsh. Temperature also clearly relates to seasonal patterns within southern Iraq.

The seasonal existence of marine species indicates that the restored Al-Hammar Marsh plays a vital part in the recovery of fisheries (Tenualosa ilisha, Liza subviridis, 
L. klunzingeri and the shrimp Metapenaeus affinis) of the north-western Arabian Gulf after becoming noticeably degraded during the period of desiccation of the AlHammar Marsh in the 1990s. Al-Yamani et al. (2007) indicated a close interrelationship between the southern Iraqi marshes and the environment of the north-western Arabian Gulf.

It seems that the restored Al-Hammar Marsh plays a role as a feeding and nursery ground for juveniles of marine species like Tenualosa ilisha, Liza subviridis and Thryssa whiteheadi, thick submergent plants like Ceratophyllum demersum offering a suitable cover from predatory fishes like Aspius vorax and Silurus triostegus, and from waterfowl. Globally, tidal marshes have a higher biological productivity than other freshwater marshes and offer protection from large marine predators.

The extreme dessciation of the marshes of southern Iraq in August 2009, as evidenced by satellite imagery, has destroyed the role of this marsh in the ecology of the fish fauna. It may still recover again if climate improves and a sufficient supply of water is released from upriver countries.

\section{Acknowledgements}

Our gratitude goes to CIMI (Canadian-Iraqi Marshes Initiative) project and the Canadian International Development Agency (CIDA) of Canada for their generous financial support without which this work would never have been achieved.

\section{References}

Ahmed HA, Al-Mukhtar MA, Al-Adhub AHY (1984) The reproductive biology of Carasobarbus luteus (Pisces, Cyprinidae) in Al-Hammar Marsh, Iraq. Cybium 8(4): 69-80.

Al-Daham NK (1982) The ichthyofauna of Iraq and the Arab Gulf. A check-list. Publications of the Basrah Natural History Museum 4: 120 pp.

Al-Hilli MR (1977) Studies on the plant ecology of the Ahwar region in southern Iraq. PhD thesis, Cairo: University of Cairo.

Al-Hilli MRA, Warner BG, Asuda T, Douabul A (2009) An assessment of vegetation and environmental controls in the1970s of the Mesopotamian wetlands of southern Iraq. Wetlands Ecology and Management (in press).

Ali TS, Hussain NA (1990) Composition and seasonal fluctuations of intertidal fish assemblage in Khor Al-Zubair, Northwestern Arabian Gulf, Iraq. Journal of Applied Ichthyology 6: 24-34.

Al-Kanaani SM (1989) Diet overlap among the common carp Cyprinus carpio L. and three native fish species in Al-Hammar marshes, southern Iraq. MSc. thesis, Basrah: Basrah University. 118 pp.

Al-Mayah AA (1992) Aquatic plants in marshes of south of Iraq, p. 127-148, in Hussain NA (Ed). Ahwar of Iraq: An environmental Approach. Marine Science Center Publication, University of Basrah 18: 299 pp. 
Al-Rikabi HUK (1992) An ecological and physiological study for some aquatic plants in AlHammar Marsh. MSc thesis, Basrah: Basrah University.

Al-Rudainy AJ, Mosa KM, Abulhani A, Ruhaij AM, Ali HA (2001) Some biological aspects of fishes collected from Al-Maathide and Beajan regions in Al-Qadisiya dam lake. Scientific Journal of the Iraqi Atomic Energy Commission 3(1): 26-39.

Al-Rudainy AJ, Ruhiage AM, Qatee AJ, Hussein TS (1999) Some biological aspects of fishes collected from Al-Habbaniya Lake. Iraqi Journal of Agriculture (Special Issue) 4(5): 159-167.

Al-Saadi HA, Antoine SE,.Nurul Islam AKM (1981) Limnological investigation in Al-Hammar Marsh area in Southern Iraq. Nova Hedwigia. 35: 157-166.

Al-Sayab AAZ (1989) Ecology and Biology of the Asiatic catfish Silurus triostegus Heckel, 1843, Pisces Siluridae from Al-Hammar marshes southern Iraq. MSc. thesis, Basrah: Basrah University. $121 \mathrm{pp}$.

Al-Sodani HM, Abed JM, Al-Essa SAK, Hammadi NS (2007) Quantitative and qualitative study on zooplankton in restored southern Iraqi marshes. Marsh Bulletin 2: 43-63.

Al-Yamani FY, Bishop JM, Al-Rifaie K, Isamail W (2007) The effects of the river diversion, Mesopotamian marsh drainage and river damming on the marine environment of the northwestern Arabian Gulf. Aquatic Ecosystem Health and Management 10(3): 277-289.

Al-Zubaidy AJM (1985) Ecological study on Algae (Phytoplankton) to the marshes near Qurna, Southern Iraq. MSc thesis, Basrah: Basrah University. 95 pp.

Aqrawi AAM (1993) Implications of sea-level fluctuations, sedimentation an neotectonics for the evolution of the marshlands (Ahwar) of southern Mesopotamia. Quaternary Proceedings 3:17-26.

Aqrawi AAM, Evans G (1994) Sedimentation in the lakes and marshes (Ahwar) of the TigrisEuphrates delta, southern Mesopotamia. Sedimentology 41(4): 755-776.

ARDI (2006) Marshlands monitoring. Final report, Development Alternative International, Agriculture Reconstruction and Development Program for Iraq (ARDI), U.S. Agency for International Development, Washington. $172 \mathrm{pp}$.

Barak NAA, Mohamed ARM (1983) Biological study of the cyprinid fish, Barbus luteus (Heckel) in Garma Marshes. Journal of Biological Sciences Research, Baghdad 14(2): 53-70.

Beckman WC (1962) The freshwater fishes of Syria and their general biology and management. Food and Agriculture Organization, Rome, Fisheries Biology Technical Paper 8: v + 297 pp.

Boesch DF (1977) Application of numerical classification in ecological investigations of water pollution. U.S. Environmental Protection Agency Ecological Research Series, EPA-600/3-77033, Corvallis, Oregon. Ix +115 pp.

CIMI (2006) Species composition, ecological indices, length frequency and food habits of fish assemblages of the restored southern Iraqi marshes. Fish Ecology Report, Canadian-Iraqi Marshes Initiative (CIMI). 172 pp.

Coad BW (1991) Fishes of the Tigris-Euphrates Basin: A Critical Checklist. Syllogeus, Ottawa 68: 49 pp.

Dawood AH (1986) The biology of common carp (Cyprinus carpio) in Hor Al-Hammar marsh, southern Iraq. MSc thesis, Basrah: University of Basrah. 94 pp.

Epler P, Bartal R, Szczerbowski JA, Szypula J (2001) The ichthyofauna of lakes Habbaniya, Tharthar and Razzazah. Archiwum Rybactwa Polskiego 9(supplement 1): 171-184. 
Evans MI (2002) The Ecosystem, p. 201-219 in Nicholson E, Clark P (Eds). The Iraqi Marshlands: A Human and Environmental Study. The Amar International Charitable Foundation, London. $\mathrm{Xv}+332 \mathrm{pp}$.

FAO (1999) Fishery country profile. FID/CP/IRQ Rev. 2.

Hammadi NS, Jasim AQ, Al-Sodani HM (2007) Occurrence and seasonal variations of phytoplankton in the restored marshes of southern Iraq. Marsh Bulletin 2: 96-109.

Hussain NA, Mohamed ARM, Al-Noor SA, Coad B, Mutlak FM, Ibrahem M, Al-Sudani IM, Mojer AM, Toman AJ, Abdad MA (2006) Species composition, ecological indices, length frequencies and food habits of fish assemblages of the restored southern Iraqi marshes. Annual final fish report. Basrah University, Iraq and Waterloo University, Canada. 114 pp. Hussain NA, Saoud HA, Al-Shami EJ (2008) Species composition and ecological indices of fishes in the restored marshes of southern Mesopotamia. Marsh Bulletin 3:17-31.

Hussain NA, Taher MA (2007) Effect of daily variations, diurnal fluctuations and tidal stage on water parameters of East Hammar marshland, Southern Iraq. Marsh Bulletin 2: 32-42. IMRP (2006) Monitor marsh ecosystem recovery. Iraq Marshlands Restoration Program (IMRP), Final Report, USAID/ Development Alternative Inc. 528 pp.

Iraq Foundation (2003) Physical characteristic of Mesopotamian marshlands of southern Iraq. Draft report, Iraq Foundation. 45 pp.

Jasim AAW (1988) Reproductive biology of Barbus sharpeyi Gunther 1874 (Pisces, Cyprinidae) south Al-Hammar marsh, Iraq. MSc thesis, Basrah: University of Basrah. 89 pp.

Khalaf KT (1961) The marine and fresh water fishes of Iraq. Ar-Rabitta Press, Baghdad. 164 pp. Mahdi N (1962) Fishes of Iraq. Ministry of Education, Baghdad. 82 pp.

Margalef R (1968) Perspectives in ecological theory. University of Chicago Press. 111 pp.

Mohamed ARM., Hussain NA., Al-Noor SS, Coad B., and Mutlak FM (2009) Status of diadromous fish species in the restored East Hammar marsh in southern Iraq, p. 577-588. In: Haro AJ, Smith KL, Rulifson RA, Moffitt CM, Klauda RJ, Dadswell MJ, Cunjak RA, Cooper JE, Beal KL and Avery TS (Eds.). $2^{\text {nd }}$ International Symposium on Diadromous Fishes, Challenges for Diadromous Fishes in a Dynamic Global Environment, 18-22 June 2007, Halifax, Nova Scotia, Canada, American Fisheries Society Symposium 69: 943 pp.

Naama AK, Ahmed HA, Al-Adhub AHY (1986) Aspects of reproduction of the mullet Liza abu (Heckel) (Pisces, Mugilidae) in Al-Hammar Marsh, Iraq. Cybium 10(1): 47-55.

Odum WE (1970) Insidious alteration of the estuarine environment. Transactions of the American Fisheries Society 99: 836-847.

Partow H (2001) The Mesopotamian Marshlands: Demise of an Ecosystem. Early Warning and Assessment Technical Report, United Nations Environment Programme, Nairobi, NEP/ DEWA/TR.01-3 Rev. 1:x + 47 pp.

Pielou EC (1977) Mathematical ecology. John Wiley, New York. 386 pp.

Richardson CJ (2008) Wetlands of mass destruction: can the garden of Eden be fully restored? National Wetlands Newsletter 30: 2-7.

Richardson CJ Hussain NA (2006) Restoring the Garden of Eden: An ecological assessment of the marshes of Iraq. BioScience 56(6): 477-489.

Shanon CE Weaver W (1949) The Mathematical Theory of Communication. University of Illinois Press, Urbana. 117 pp. 
Tahir MA, Risen AK, Hussain NA (2008) Monthly variations in the physical and chemical properties of the restored southern Iraq marshes. Marsh Bulletin 3: 81-94.

Tyler AV (1971) Periodic and resident components in communities of Atlantic fishes. Journal of the Fisheries Research Board of Canada 28(7): 935-946.

UNEP/IMOS (2007) Iraqi marshland observation system. United Nations Environmental Programme, Iraqi Marshlands Observation System, http://imos.grid.unep.ch. 